\title{
Foreign Direct Investment and Economic Stability: The case of Arab Peninsula
}

\author{
Dr. Abdulrahman Al-Fawwaz \\ Associate Professor \\ Department of Humanities, Al-Balqa' Applied University \\ P.O.Box: 15008 Amman 11134 Jordan \\ Dr. Fawaz. M. Al-khraisha \\ Ph.D in Law \\ Ministry of Interior, Amman-Jordan \\ Dr. Riyad. M. Al-Khlaifat \\ Assistant Professor \\ AL-Balqa' Applied University,AL-Huson, Jordan.
}

\begin{abstract}
Purpose - The purpose of this research paper is to present the study regarding foreign direct investment and its relationship with economic stability. The case of Arab peninsula is discussed throughout the paper. Methodology - The secondary research design was selected and the exploratory study was conducted. The time series analysis was presented by exploring the FDI investment in Oman, Jordan, Saudi Arabia, Kuwait, Bahrain and Qatar. The data three-year data was collected by studying the FDI investment reports shared by Santander Trade. Findings - The findings of study presents the information regarding increase and decrease in FDI in countries from Arab Peninsula. The findings show that Qatar, Kuwait and Bahrain are able to accelerate their FDIs due to political and economic stability, but Saudi Arabia, Oman and Jordan are having downward FDI trend. Implications - This paper benefits academically and practically by providing the three years trend which can help investors to explore the favourable countries within Arab Peninsula for FDIs. On another side, the academic practitioners can utilize this study to conduct the future study by comparing least and most significant countries within Arab Peninsula for foreign investments.
\end{abstract}

Keywords: Foreign Direct Investment (FDI), Arab Peninsula, Globalization, Bilateral ties and Political Instability

\section{Overview}

\section{INTRODUCTION}

Foreign direct investments (FDIs) play an imperative role in the developing economies as it has been examined as one of the contributing factors towards economic stability. It has increasing implications for the economic development because it leads the economy towards internationalization, stimulated by trade technology, financial flows, and accessibility towards the resources (Guerin, and Manzocchi, 2009). Viewing the global perspective, FDIs is one of the prominent factors that helps in stimulating the economy, but it is immensely influenced by the political stability because investors from foreign markets tend to make investment plans when they find strong bilateral ties between the countries (Rotunno, 2016; Cooray, Dutta, and Mallick, 2017). 


\section{Problem Statement}

FDIs are one of those economic factors that have the ability to increase turnover of any economy and can result in the internal stability, but it is mainly supported by a stable political regime, which helps in creating a favorable situation for any foreign investor to make investments. Poor economic conditions are reported due to poor FDIs that are synchronized with the political conditions and government stability (Al-Rashid, 2015). Considering the political situation of Arab countries, it is seen that due to rising internal conflicts and external inclusion in political affairs, internal FDIs are being influenced, which as a result is creating a negative impact on the economic stability of entire Arab Peninsula. In recent scenario, due to Syrian war and the rising influence of ISIS, the economic well as the political stability of Arab Peninsula is under threat, which has increased internal conflicts and chaos, militarization, ethical and religious tensions for the region (Ianchovichina, and Ivanic, 2016). Therefore, the problem statement of the study is to analyze the relationship between FDI and economic stability under the influence of various socio-economic and political determinants.

\section{Background}

The course of globalization and the intensive outlook towards bilateral ties reveals that political regime tends to influences the internal investments and trading. Democratic economies tend to set lower barriers for trading; thus resulting in forming open trade relationship with the political alliance countries. Apparently, FDI influences the economic growth, but political relations are the source towards increasing FDIs for any economy. In this regard, Harrigan, and Reshef, (2015) presented the argument that democratization results in trade liberalization that is skill-biased (Lin, and Fu, 2016). The argument is further supported by the idea, which states that have autocratic political setup tend to trade substantially lesser comparative to democratic political systems because, in autocratic setup, political elites impose more trading barriers or the policies tends to be relatively strict (Cervellati, Naghavi, and Toubal, 2013; Guerin, and Manzocchi, 2009).

Foreign direct investments by various multinational institutions have grown immensely in last few decades within developing countries and results in their economic development. It has become the soul of creating a better trading environment that is accompanied by formal and informal bilateral ties with the neighboring and foreign economies. However, in the Arab states, the investments fall by $8 \%$ which were $\$ 43.9$ billion in 2014, whereas, in 2013 , the investments were $\$ 47$ billion (YourMiddleEast, 2015). Besides, in 2008, the decline in the FDI level was also witnessed in the Arab region that clearly illustrates the overall impact on the inflow of investments due to global crisis. In different countries of the Arab Peninsula, the challenges are different that are more or less related to determinants related to politics. In Jordan, the major political challenge is corruption, whereas, in Lebanon, the challenges are mainly due to poor labor regulations and more sanctions on trading (Al-Rashid, 2015).

\section{Aims of the Research}

The aim of the study is to investigate and analyze the relationship between FDIs and economic stability that is affected due to political instability in the Arab peninsula.

\section{Research Questions}

[1] How influential the relationship of FDIs is with the economic growth?

[2] What are the socio-economic and political key determinants that influence inward investment decisions?

[3] How political instability affected the inflow of FDI in the economic growth of Arab Peninsula? 


\section{Significance of the Research}

The study plays a significant part in sharing concrete and comprehensive understanding about FDIs in Arab countries, mainly the Arab belt that is suffering from war and poor political situation. It shares understanding about the effect that internal conflicts within this region created on economic stability and reduced the inflow of FDIs, thus resulting in unemployment, higher inflation, and poverty. The key political determinants that are discussed in the study are internal conflicts and chaos, external conflicts (poor bilateral ties and alliances), government instability, militarization, corruption in Arab countries, religious influences (like ISIS), war situations, and ethical tensions. Considering the latest situation, the study will play an imperative role to analyze the issue by means of exploratory research method. Further, the study also plays a significant role in adding knowledge to future academic practitioners to understand the link between FDIs and economic stability in the light of socio-economic and political determinants.

\section{Foreign Direct Investment}

\section{LITERATURE REVIEW}

The foreign direct investment is the phenomena, which is resulting due to globalization and it involves the integration of the domestic economic system with the global markets. The phenomena of foreign direct investment are accompanied through market openness and political stability which enhances the domestic capital in the economy. Moran (2012), unfold the main reason behind the increase in direct investment and mentioned that the technological advancement emerged the more efficient means to communicate and transport which led an investor to think beyond the political boundaries. Especially, in the post-colonial era the firms acquired independence and the phenomena of globalization influence the trade among investors and the foreign countries, thereby it refers to the theory of comparative advantage where the countries with scarce resources trade with counties with abundance resources to gain potential benefits. Therefore, as economies expanded the exchange of goods, services and trade grew which continued to the advancement.

The studies of Iamsiraroj and Ulubaşoğlu (2015); Amri (2016); Solomon (2017) elucidated that foreign direct investment plays key contribution in the growth of economy implicitly and explicitly as it is the cross-border investment. The investment is significant that boost the economic growth and the FDI leads towards positive externalities which in addition increases the growth level of the technological spillover effects. The inward flow of FDI also benefits host economy to transmit knowledge, technology and manufacturing capabilities as it cumulatively increases the gross domestic problems due to increase in sales and production of the company.

However, multiple studies of scholars such as Shahbaz, Nasreen, Abbas, and Anis (2015), mentioned the political risk associated with FDI; Carkovic and Levine (2005), highlighted loss in investment returns due to political instability and the study of Zhang (2001), mentioned military control that affects the investment decisions. Aside from these studies the recent studies of Iamsiraroj and Ulubaşoğlu (2015); Amri (2016); Solomon (2017), mentioned that despite economic stability the FDI can positively or negatively influence on environmental regulations, military politics, law and order, internal conflicts, external conflicts, religion polities, labor laws, trade tariffs, spending and currency valuation.

\section{Foreign Direct Investment and Economic Stability in Arab Region}

The foreign direct investment is linked with the economic development especially in term of positive development. The concept impact of FDI on economic growth and development has been focused in endogenous growth models of Rubelo, Lucas, Romer and other new classical theorists such as Cobb-Douglas and Solow that focused upon the political and economic perspective of FDI rather than technological or humanistic (Shahbaz, Nasreen, Abbas and Anis, 
2015). Numerous studies have been conducted, which examined the impact of FDI in increasing the per capita income and its contribution to socio-economic and political development (Efobi, Asongu, and Beecroft, 2015).

The Arab region contains 22 countries that show the formal and common Arabic language (Appendix A). During 1944 majority of Arab countries established the League of Arab states which was joined by other countries and the main goal was to enhance the (i) relationship among member state (ii) Safeguard the sovereignty and independence (iii) Coordinate and collaborate. The Arab monetary fund is an example of Regional Arab organizations, which started its operations in 1977 and served 22 counties. Its core aim is to promote financial markets in Arab counties, established policies, remove restriction and encourage monetary cooperation (Moran, 2012). According to AMF, the countries are classified into three major groups which include:

Table 1: Arab Peninsula Countries

\begin{tabular}{|c|c|c|}
\hline $\begin{array}{l}\text { Gulf } \\
\text { Cooperation } \\
\text { Council (GCC) }\end{array}$ & $\begin{array}{l}\text { Oman, Qatar, Kuwait, } \\
\text { UAE, Bahrain and } \\
\text { Saudi Arabia }\end{array}$ & $\begin{array}{l}\text { These countries are politically } \\
\text { stable and they have open trading } \\
\text { and financial system to export oil, } \\
\text { gas, natural resources and } \\
\text { promote inward FDIs }\end{array}$ \\
\hline $\begin{array}{l}\text { Oil exporter } \\
\text { countries }\end{array}$ & $\begin{array}{l}\text { Iraq, Sudan, Algeria, } \\
\text { Libya and Yemen }\end{array}$ & $\begin{array}{l}\text { They export oil and are lesser } \\
\text { open in foreign markets for } \\
\text { inward FDI }\end{array}$ \\
\hline $\begin{array}{l}\text { Diversified } \\
\text { economies }\end{array}$ & $\begin{array}{l}\text { Jordan, Egypt, } \\
\text { Comoros, Djibouti } \\
\text { Syria, Palestine, } \\
\text { Morocco, Lebanon, } \\
\text { Tunisia, Mauritania, } \\
\text { and Somalia }\end{array}$ & $\begin{array}{l}\text { These countries significantly } \\
\text { relies upon inward and outward } \\
\text { FDI and they have range of } \\
\text { profitable sectors such as } \\
\text { agriculture, textiles, tourism, and } \\
\text { banking, which plays major role } \\
\text { in economic development and it } \\
\text { encourages investors }\end{array}$ \\
\hline
\end{tabular}

Source: Iamsiraroj and Ulubaşoğlu (2015)

As highlighted by Amri (2016), the FDI inflow grew in Arab countries from 2004 to 2012 due to political and economic stability. The increase in oil prices, political stability, technological improvement and economic reforms created a positive business climate and during 2008 the Arab region reached to the peak of US $\$ 97$ billion (Bekhet and Al-Smadi, 2015). However, the global financial crises affect the Arab region and by 2009 the $15.5 \%$ decline was seen. However, 2012, 2015 the increase in FDI inflow was by $15.3 \%$ to $19 \%$. The below table presents the FDI inflows in Arab countries from the period of 2004 to 20115 below figure:

Figure 1: FDI inflows

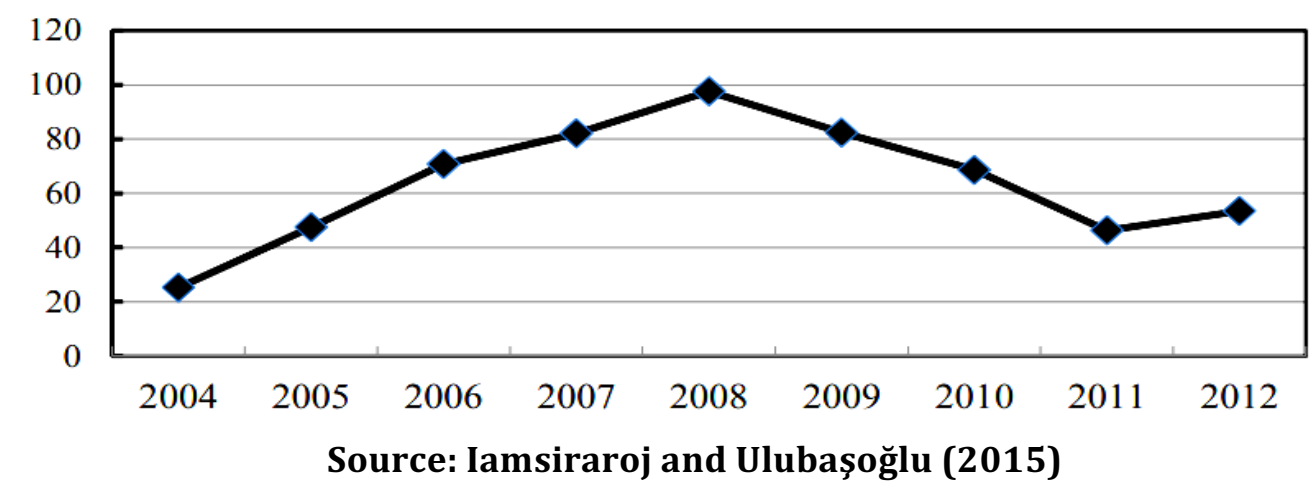




\section{Impact of Socio-Economic and Political Factors on Foreign Direct Investment}

The economic growth of emerging countries and market depends upon the possibilities to accumulate capital and profitable investment. The access to foreign capital allows the country to exploit the opportunities and it attracts foreign investors. Various authors such as Shahbaz, Nasreen, Abbas, and Anis (2015); Solomon (2017); justified the impact of FDI on economic development statistically, but simultaneously the scholars identified a wide range of economic and political determinants that are discussed below:

Table 2: Determinants of FDI

\begin{tabular}{|c|c|c|}
\hline Determinants & Explanations & Sources \\
\hline $\begin{array}{l}\text { Government } \\
\text { Stability }\end{array}$ & $\begin{array}{l}\text { It refers to the ability of government } \\
\text { to develop efficient macroeconomic } \\
\text { policies and ability to pay off the } \\
\text { debts quickly }\end{array}$ & Solomon (2017) \\
\hline $\begin{array}{l}\text { Socio-economic } \\
\text { conditions }\end{array}$ & $\begin{array}{l}\text { It refers to the social and economic } \\
\text { condition that arise from government } \\
\text { actions and social dissatisfaction }\end{array}$ & $\begin{array}{l}\text { Shahbaz, Nasreen, Abbas, and } \\
\text { Anis (2015) }\end{array}$ \\
\hline Internal Conflicts & $\begin{array}{l}\text { It refers to the political violence } \\
\text { within the nation and its potential } \\
\text { and actual impact on the governance. } \\
\text { It includes civil disorder, civil war, } \\
\text { terrorism and civil disorder }\end{array}$ & Bekhet and Al-Smadi, (2015) \\
\hline External Conflicts & $\begin{array}{l}\text { It refers to the incumbent risk from } \\
\text { foreign markets and the non-violence } \\
\text { external pressure such as cross- } \\
\text { border conflicts }\end{array}$ & Moran (2012) \\
\hline Military in Politics & $\begin{array}{l}\text { It refers to the military influence in } \\
\text { the political and economic affairs, } \\
\text { which shows the inability of } \\
\text { government to function efficiently }\end{array}$ & Osabutey and Okoro (2015); \\
\hline Ethical tensions & $\begin{array}{l}\text { It refers to the degree of tension } \\
\text { between the racial, ethical, language } \\
\text { or national divisions }\end{array}$ & Kariuki (2015); \\
\hline $\begin{array}{l}\text { Democratic } \\
\text { Accountability }\end{array}$ & $\begin{array}{l}\text { It shows the responsiveness of } \\
\text { government towards its political } \\
\text { rights and civil liberties }\end{array}$ & Rodan (2016) \\
\hline Religion in Politics & $\begin{array}{l}\text { It refers to the religious tension due } \\
\text { to governance by single religious } \\
\text { group or the replacement of civil } \\
\text { with religious law or elimination of } \\
\text { religion from social or political } \\
\text { process }\end{array}$ & $\begin{array}{l}\text { Iamsiraroj and Ulubaşoğlu } \\
\text { (2015) }\end{array}$ \\
\hline
\end{tabular}

\section{Source: Iamsiraroj and Ulubaşoğlu (2015)}

The Uppsala model is the behavioral theory of firm which was influenced by the theory of Penrose that relates to the growth of the firm. The Uppsala Model school of thought considers FDIs as the operations conducted by business in overseas market; thus the model justifies the potential risk due to culture, political, economic and market condition (Kim and Li, 2014). It is seen that the macro environmental factors have greater impact on the business decisions for expansions. Therefore, the investments are also suffered due to macro environmental factors. The model suggests that the firm must gradually involve into the foreign market through taking progressive actions. Receiving foreign investments can help not only businesses, but the environment is also influenced based upon growth (Dentinho, and Silva, 2017). Due to FDIs, 
the chance of economic development and social stability becomes obvious. It gives a chance to people of the country to enhance their living standards and this reduces in reducing the inflation rate as well (Shen, and Puig, 2018). The model suggests that the international experiences are divided into two categories, which includes general and specific international experiences. The strategic planning results in mutual benefits of home and host country, which also mitigate the negative effect resulting from social-economic and political instability. Hence, the role of FDIs tends to be influential in turning the poor economy into growing economy.

Besides this, scholars such as Osabutey and Okoro (2015); Kariuki (2015); Rodan (2016) mentioned the location-specific factors, which allow investors from home country to identify the effectiveness of host country. The main determinant identified by the scholar was the potential risk, which affects the expected outcome of the investment. Pandya (2014) explained the political risk as the risk, which can affect the business environment and its operations. It not only influences the operational execution of the business at one hand, but also turns the economy into dark because due to political instability, the social and economic instability is seen. However, the worst consequences are seen when the social instability and the chaos is witnessed, which makes the people of the state more frustrated. Brahim and Rachdi (2014), mentioned 12 indicate of the political risk which is based on the international country risk guide (ICRG). The outcome of studies proved that the Arab counties with low political risk and better institution irrespective of government stability. This is mainly due to the political alliance that is seen in the Arab countries that helps in giving an equal opportunity to small countries that are underdeveloped to enhance their socio-economic conditions.

\section{METHODS}

\section{Methods}

The issue discussed in the study was about analysing the relationship between FDIs and economic stability in the light of socio-economic and political determinants and the analysis was done on the case of Arab Peninsula; therefore, the methods suitable for the study were secondary approaches. The study indented to analyse the present situation that is influenced by several factors. Data gathering was done based upon approaching the secondary sources of information that helped in knowing the specific challenges Arab region is facing towards receiving FDIs that is affecting its economic and social stability. However, the reason identified from the literature review was that the FDIs are being affected due to poor political situation and the chaos that is being faced as the result of war.

Hence, the philosophical approach suitable on the paradigm of the study was 'Social Constructivism'. It is the theory that is related to exploring any actual phenomenon by focusing upon its in-depth aspects. The philosophical approach focuses upon a single phenomenon and its relation to the concept that helps in knowing its practical side (Andrew, Pedersen, and McEvoy, 2011). The philosophical approach also supports in applying the exploratory research design on the study where gathering new evidences helped in investigating the issue. The reason to choose exploratory research design was that it helped to analyse the phenomenon by defining a problem and then searching the relevant secondary content so that the analysis can be done. Therefore, a brief problem statement was designed in the study that directs towards gathering the relevant facts and theoretical evidences (Ioannidis, Greenland, Hlatky, Khoury, Macleod, Moher, Schulz, and Tibshirani, 2014).

\section{Material}

The material that was used to present the analysis on the issue was taken from the secondary sources. Mainly, various official documents such as published official reports on economic development have been used. To analyse the case, multiple published articles were also used 
and online content was accessed because much information can be seen on websites, (mainly newspapers, online articles, and reports). Hence, much have been gathered on understanding the current situation of Arab Peninsula by accessing the FDIs report shared by Santander Trade. The time series analysis was conducted and the data was taken from 2014 to 2016. The report shared by Satander Trade helped in analyzing the current situation of FDIs inflow in Arab Peninsula and 3 years trend. The secondary data helped in revealing some informative facts such as the decrease in FDIs in specific regions of Arab Peninsula including Oman, Jordan, Bahrain, Kuwait, Saudi Arabia and Qatar.

\section{Analysis}

Arabian Peninsula is the western Asia which is situated in Africa on the Arabian plate. It is considered as the subcontinent in Asia and recognized as the largest peninsula of a world with $3,237,500 \mathrm{~km}$. The counties that fall under Arab Peninsula are Qatar, Yemen, Kuwait, Bahrain, UAE, Jordan, Iraq and Saudi Arabia. Qatar is the leading country in foreign direct investment and international business. From past few years due to political stability the country has 774 million FDI inflows due to lowest corporate tax in the world (Ulrichsen, 2009). Qatar also develops high-quality infrastructure and enacted investment laws which allow foreigner to own totality of company in industries such as consulting, information technology, sports, culture and distribution. Since 2015 the country also made improvement in foreign working conditions which expanded the FDI inflows in Qatar. The below figure shows the trend analysis of three years FDI inflows in Qatar:

Table 3: FDI inflows in Qatar

\begin{tabular}{|l|c|c|c|}
\hline Foreign Direct Investment Qatar & $\mathbf{2 0 1 6}$ & $\mathbf{2 0 1 5}$ & $\mathbf{2 0 1 4}$ \\
\hline FDI Inward Flow (million USD) & 774 & 1,071 & 1,040 \\
\hline $\begin{array}{l}\text { Number of Greenfield } \\
\text { Investments }\end{array}$ & 33 & 35 & 54 \\
\hline FDI Stock (million USD) & $33,943.10$ & 33.169 .2 & $32,098.30$ \\
\hline FDI Stock (in \% of GDP) & 21.7 & 20.1 & 15.6 \\
\hline FDI Inwards (in \% of GFCF) & 0.8 & 1.2 & 1.4 \\
\hline
\end{tabular}

Source: Santander, (2018)

Likewise, Qatar, Kuwait is also actively promoting the inward FDI especially in its petrochemical industry. The country encourages the entry of foreign banks and develops the law on taxation policy for foreign companies which decrease the tax rate on profits (Odhiambo, 2017). The existing policy of Kuwait promotes FDI in infrastructure development, communication technology, waste and water treatment, banking sector, insurance sector, software development, hospitals along with attraction foreign capital in tourism, urban development and freight. The below figure presents the trend analysis of three years FDI inflows in Kuwait:

Table 4: FDI inflows in Kuwait:

\begin{tabular}{|l|c|c|c|}
\hline Foreign Direct Investment Kuwait & $\mathbf{2 0 1 6}$ & $\mathbf{2 0 1 5}$ & $\mathbf{2 0 1 4}$ \\
\hline FDI Inward Flow (million USD) & 275 & 294 & 954 \\
\hline $\begin{array}{l}\text { Number of Greenfield } \\
\text { Investments }\end{array}$ & 31 & 17 & 24 \\
\hline FDI Stock (million USD) & 14,260 & 14,604 & 15,733 \\
\hline FDI Stock (in \% of GDP) & 13 & 12.8 & 9.7 \\
\hline FDI Inwards (in \% of GFCF & 1 & 1 & 3.6 \\
\hline
\end{tabular}

Source: Santander, (2018) 
In Arab peninsula, Bahrain is another country with positive FDIs and during 2016 about 280 million USD FDI inflows have been reported. According to Bahrain economic development 142 million, \$ were invested by 22 companies and the tourism accounted for three-quarter of FDI flows. The manufacturing accounted for 15\%; whereas financial services accounted $9 \%$. The FDI inflows were mainly from US, Germany, China and India (Odhiambo, 2017). The Bahrain FDI stock recovered the global financial crises and political instability. However, Bahrain remains under challenge due to the rigid labour market and lack of privatization. The below figure presents the trend analysis of three years FDI inflows in Bahrain:

Table 5: FDI inflows in Bahrain

\begin{tabular}{|l|c|c|c|}
\hline $\begin{array}{l}\text { Foreign Direct Investment } \\
\text { Bahrain }\end{array}$ & $\mathbf{2 0 1 6}$ & $\mathbf{2 0 1 5}$ & $\mathbf{2 0 1 4}$ \\
\hline FDI Inward Flow (million USD) & 282 & -797 & 1,519 \\
\hline $\begin{array}{l}\text { Number of Greenfield } \\
\text { Investments*** }\end{array}$ & 35 & 38 & 33 \\
\hline FDI Stock (million USD) & 28,606 & 28,325 & 29,122 \\
\hline FDI Stock (in \% of GDP) & 89.7 & 91 & 87.2 \\
\hline FDI Inwards (in \% of GFCF***) & 3.6 & -10.7 & 17.8 \\
\hline
\end{tabular}

Source: Santander, (2018)

In countries such as Jordan, UAE and Saudi Arabia the negative and downwards FDI inflows have been reported since last 3 decades. Jordan historically appreciated massive investment by the Gulf countries. Until 2006 to 2014 the country FDI is declining due to political instability. The substantial loss was reported during 2016 and US decided to raise their annual aid by 1,275 billion. These funds in the US aim to support Jordan to greet Syrian refugees (Santander, 2018). To boost the FDI the Jordan government planned large-scale projects i.e. energy projects water projects and transportation, but it requires massive investment. In 2016 the Dead Sea project was signed by Kuwait and by 2018 the project of dead sea to red sea is expected to get started, but require FDI. Despite these unfavourable conditions Jordan is trying to become the logistics hub for transport and electric network. The below figure presents the FDI inflows in Jordan:

Table 6: FDI inflows in Jordan:

\begin{tabular}{|l|c|c|c|}
\hline Foreign Direct Investment Jordan & $\mathbf{2 0 1 6}$ & $\mathbf{2 0 1 5}$ & $\mathbf{2 0 1 4}$ \\
\hline FDI Inward Flow (million USD) & 1,539 & 1,600 & 2,179 \\
\hline $\begin{array}{l}\text { Number of Greenfield } \\
\text { Investments*** }\end{array}$ & 21 & 7 & 14 \\
\hline FDI Stock (million USD) & 32,148 & 30,629 & 29,059 \\
\hline FDI Stock (in \% of GDP) & 83 & 81.5 & 81 \\
\hline FDI Inwards (in \% of GFCF***) & 20 & 22.1 & 28.6 \\
\hline
\end{tabular}

Source: Santander, (2018)

In Oman till 2015 the FDI inflows were negative but after 2016 modest recovery has been noted in FDIs. The FDI stock has been restored after 2010 and the foreign investment is accelerating since 2016. The Sultanate of Oman is able to attract the investment by offering them tax benefits. The political stability and favourable macroeconomic condition attracted international businesses that are especially from China, Japan and US (Santander, 2018). However, one of the pressures faced by foreign companies is the recruitment of domestic workforce, which creates an obstacle in foreign investment. Majority of FDI in Oman are in oil sector and the construction of airport, seaports, refinery accelerate the tourism facility. The below figure shows the FDI inflows in Oman: 
Table 7: FDI inflows in Oman

\begin{tabular}{|l|c|c|c|}
\hline Foreign Direct Investment Oman & 2016 & 2015 & 2014 \\
\hline FDI Inward Flow (million USD) & 142 & $-2,692$ & 1,506 \\
\hline $\begin{array}{l}\text { Number of Greenfield } \\
\text { Investments*** }\end{array}$ & 36 & 42 & 42 \\
\hline FDI Stock (million USD) & $18,547.70$ & $18,405.70$ & $21,097.70$ \\
\hline FDI Stock (in \% of GDP) & 29.4 & 26.4 & 26 \\
\hline FDI Inwards (in \% of GFCF***) & 0.6 & -11.4 & 6.5 \\
\hline
\end{tabular}

Source: Santander, (2018)

Similarly to Oman, FDI inflows in Saudi Arabia are following downward trends and according to world investment Report (UNCTAD), the KSA is the third largest FDI recipients in western Asia. In 2016 the FDI inflows felt by $8.5 \%$ compared to 2015, which was the lowest value since 2014. The reason for the downward trend is due to political tension and economic instability. Besides this, the policy of Saudization also creates a huge obstacle in FDI inflows. The below figure represents the trend analysis of FDI inflow in KSA:

Table 8: FDI inflow in KSA

\begin{tabular}{|l|c|c|c|}
\hline Foreign Direct Investment Saudi Arabia & $\mathbf{2 0 1 6}$ & $\mathbf{2 0 1 5}$ & $\mathbf{2 0 1 4}$ \\
\hline FDI Inward Flow (million USD) & 7,453 & 8,141 & 8,012 \\
\hline Number of Greenfield Investments*** & 90 & 92 & 97 \\
\hline FDI Stock (million USD) & 231,502 & 224,050 & 215,909 \\
\hline FDI Stock (in \% of GDP) & 36.2 & 34.4 & 28.5 \\
\hline FDI Inwards (in \% of GFCF ( $^{* * * *}$ ) & 4.5 & 4.2 & 4.2 \\
\hline
\end{tabular}

Source: Santander, (2018)

FDI plays a significant part in the development of the country and it creates global integration through training and development, transfer of knowledge, development of human capital and sharing of operational expertise. Before investing in any country the investor looks after following factors:

I. Availability of Infrastructure

II. Social and political stability

III. Availability of Skilled workers

IV. Tax regimes

V. Market size

VI. Per capita income

VII. Foreign exchange rules and regulations

Considering these factors the below is the analysis of countries that fall under Arab peninsula: 
Table 9: Weak and Strong Determinates of FDIs

\begin{tabular}{|c|c|c|}
\hline Countries & Weak Point towards FDIs & $\begin{array}{l}\text { Strong Point towards } \\
\text { FDIs }\end{array}$ \\
\hline Bahrain & $\begin{array}{l}\text { Political and civil upheaval } \\
\text { Officials travel bans } \\
\text { Difficulty in obtaining work } \\
\text { permits } \\
\text { Corruption and government } \\
\text { interventions in tenders }\end{array}$ & $\begin{array}{l}\text { English speaking and } \\
\text { educated population } \\
\text { Cultural openness } \\
\text { Strategic location } \\
\text { Attractive tax regime }\end{array}$ \\
\hline Saudi Arab & $\begin{array}{l}\text { Inadequate legal framework } \\
\text { Lack of transparency } \\
\text { Delayed in payments } \\
\text { Conservative cultural } \\
\text { environment } \\
\text { Segregation of sexes }\end{array}$ & $\begin{array}{l}\text { Economic stability } \\
\text { High spending power } \\
\text { Quality infrastructure } \\
\text { Well regulated banking } \\
\text { system }\end{array}$ \\
\hline Kuwait & $\begin{array}{l}\text { Dependent on oil } \\
\text { Lack of protection towards } \\
\text { intellectual property }\end{array}$ & $\begin{array}{l}\text { High living standards } \\
\text { Abundance oil reserves } \\
\text { Consumer demand for } \\
\text { foreign products } \\
\text { Strong banking system } \\
\text { Absence of taxes }\end{array}$ \\
\hline Jordan & $\begin{array}{l}\text { Unstable region due to Iraq, } \\
\text { Syrian and Israel conflicts } \\
\text { Massive influx of refugees } \\
\text { from Iraq } \\
\text { Lack f natural resources } \\
\text { Dependent upon foreign aid }\end{array}$ & $\begin{array}{l}\text { Well trained workforce } \\
\text { Geographical location }\end{array}$ \\
\hline
\end{tabular}

Source: Santander, (2018)

\section{DISCUSSION}

The economic structure of the Arab world is not monolithic, but it has unified system. It had heterogeneous economies that are placed at different economic development stages. However, the prevalent element that is considered as the binding force of the Arab counties is that these are the Islamic states and based upon Islamic civilization. They major economic growth and productivity is based upon two categories that include [1] non-oil production states, and [2] oil production states. The oil production states are the GCC member countries, whereas the nonoil production states are Jordan, Syria, Morocco, and Egypt (Noland and Pack, 2008). This GCC countries economic growth is mainly rely upon the oil production and in case of any depletion in the oil production, then the economy suffers and fluctuation is seen. At present, from the analysis, it is identified that the Arab Peninsula is facing major challenges due to structural weaknesses that is hampering the ability of these countries in making the transition towards being productive economic system (Benchea, 2015). The analysis revealed the following constraints at macro-economic and political level:

[1] Dependence on the oil revenues, as the dominance of production is on oil revenue, therefore the growth in GDP is majorly based upon oil production. This gives the 70\% exports to the region, resulting in economic growth. However, the major political instability seen in this region is due to oil and natural gas, and this has majorly increases foreign intervention in the political stability of the region (Benchea, 2015).

[2] The major economic challenge faced by the Arab peninsula is the unemployment level. The report stated by International Labour Organisation (ILO) reveals that the Arab region has higher unemployment rate that is $10.3 \%$ comparative to the overall global unemployment rate i.e. 6.2\% (ILO, 2011). 
[3] According to the latest report of World Health Organisation (WHO), there is also water scarcity seen in the Arabian Gulf, mainly Arab Peninsula. This is due to the poor management and regulations, socio-economic instability and various other challenges as well (Odhiambo, 2017).

[4] The economic instability and poor flow of FDIs is also due to unequal distribution of natural reserves in the Gulf. Hence, this had also increased the security issues and potential tensions for the region as well that is affecting the regional development (Ulrichsen, 2009).

\section{CONCLUSIONS AND IMPLICATIONS}

The economic growth of any country is centralized based upon its entire macro-economic system. It not only involves the socio-economic factors, but there is equal insertion of political factors too. The role of FDIs is prominent in economic development and growth, but the political factors are parallel in creating an impact on economic stability. In the case of Arab Peninsula, it is seen that the FDIs are being affected by the poor political situation. This is due to the state of war that created hindrance in the economic growth and stability of the region. The interest of investors is affected due to the unstable situation and the changing political environment. At present, the economic growth of those countries in Arab Peninsula is also at risk who are not directly involve in political incongruity, but the cross-border impact has affected the investments in those countries; thus resulting a negative impact on their economic growth. The study concludes that FDIs do have major influence on the economic growth because a major portion of GDP is governed by the investments received from foreign sources, but the interest of investors is suffered when they find major constrains (mainly political instability and anarchism in the state). Hence, there is need of policy implications at governmental level in order to regulate foreign investments in the region in the course of economic stability.

The role of UAE and Saudi Arabia can be pivotal in creating political stability within Arab Peninsula. At present, it is seen that the major countries of Middle East can play a mediating role in bringing harmony within Arab Peninsula considering the enduring repercussions of poor economic development on society and future of the state. Besides, if the major actions are not taken at earlier, then a social disturbance may increase due to poverty and unemployment in the region, which may eventually affect the stability of major Middle Eastern countries (such as Saudi Arabia, UAE, Turkey, Iran etc.). Besides, aids can be given to Arab Peninsula for their redevelopment so that they can rebuild their social system. Lastly, on-going support from neighboring countries can help to overcome internal challenges where it is necessary at political level to create a barrier on foreign intervention in political affairs of these regions so that social harmony can be build.

\section{References}

Al-Rashid, H., 2015. FDI and Economic Growth in the Arab Region: The Case of Knowledge Spillover Effects.

Amri, F., 2016. The relationship amongst energy consumption, foreign direct investment and output in developed and developing countries. Renewable and Sustainable Energy Reviews, 64, pp.694-702

Andrew, P.S., Pedersen, P.M. and McEvoy, C.D. 2011. Research Methods and Designs in Sport Management. Human Kinetics.

Bekhet, H.A. and Al-Smadi, R.W., 2015. Determinants of Jordanian foreign direct investment inflows: Bounds testing approach. Economic Modelling, 46, pp.27-35.

Benchea, L.R., 2015. Rebuilding the Arab Economies: New Regional and Global Strategies. European Journal of Interdisciplinary Studies, 7(2), p.29.

Brahim, M. and Rachdi, H., 2014. Foreign direct investment, institutions and economic growth: Evidence from the MENA region. Journal of Reviews on Global Economics, 3, pp.328-339. 
Carkovic, M. and Levine, R., 2005. Does foreign direct investment accelerate economic growth?. Does foreign direct investment promote development, 195.

Cervellati, M., Naghavi, A. and Toubal, F., 2013. Trade liberalization, democratization and technology adoption.

Cooray, A., Dutta, N. and Mallick, S., 2017. Trade openness and labor force participation in Africa: the role of political institutions. Industrial Relations: A Journal of Economy and Society, 56(2), pp.319-350.

Dentinho, T. and Silva, J.R., 2017. Causes and Effects of Foreign Direct Investment in South Asia. In Regional Cooperation in South Asia (pp. 31-45). Springer, Cham.

Efobi, U., Asongu, S. and Beecroft, I., 2015. Foreign direct investment, aid and terrorism: empirical insight conditioned on corruption control.

Guerin, S.S. and Manzocchi, S., 2009. Political regime and FDI from advanced to emerging countries. Review of World economics, 145(1), pp.75-91

Harrigan, J. and Reshef, A., 2015. Skill-biased heterogeneous firms, trade liberalization and the skill premium. Canadian Journal of Economics/Revue canadienne d'économique, 48(3), pp.1024-1066.

Iamsiraroj, S. and Ulubaşoğlu, M.A., 2015. Foreign direct investment and economic growth: A real relationship or wishful thinking?. Economic Modelling, 51, pp.200-213.

Ianchovichina, E. and Ivanic, M., 2016. Economic Effects of the Syrian War and the Spread of the Islamic State on the Levant. The World Economy, 39(10), pp.1584-1627.

International Labour Organization (ILO), 2011. Statistical update on Arab States and Territories and North African Countries. Available at: http://www.ilo.org/global/statisticsand-databases/WCMS_156325/lang--en/index.htm [Accessed on $5^{\text {th }}$ Feb' 2018]

Ioannidis, J.P., Greenland, S., Hlatky, M.A., Khoury, M.J., Macleod, M.R., Moher, D., Schulz, K.F. and Tibshirani, R., 2014. Increasing value and reducing waste in research design, conduct, and analysis. The Lancet, 383(9912), pp.166-175.

Kariuki, C., 2015. The determinants of foreign direct investment in the African Union. Journal of Economics, Business and Management, 3(3), pp.346-351.

Kim, P.H. and Li, M., 2014. Injecting demand through spillovers: Foreign direct investment, domestic sociopolitical conditions, and host-country entrepreneurial activity. Journal of Business Venturing, 29(2), pp.210-231.

Lin, F. and Fu, D., 2016. Trade, institution quality and income inequality. World Development, 77, pp.129-142.

Moran, T., 2012. Foreign direct investment. The Wiley-Blackwell Encyclopedia of Globalization.

Noland, M., and Pack, H. 2008. Arab Economies at a Tipping Point. Middle East Policy XV(1).

Odhiambo, G.O., 2017. Water scarcity in the Arabian Peninsula and socio-economic implications. Applied Water Science, 7(5), pp.2479-2492.

Osabutey, E.L. and Okoro, C., 2015. Political risk and foreign direct investment in Africa: The case of the Nigerian telecommunications industry. Thunderbird International Business Review, 57(6), pp.417-429.

Pandya, S.S., 2014. Democratization and foreign direct investment liberalization, 1970-2000. International Studies Quarterly, 58(3), pp.475-488.

Rodan, G., 2016. The political economy of Singapore's industrialization: national state and international capital. Springer.

Rotunno, L., 2016. Political stability and trade agreements: Evidence for 'endgame FTAs'. European Journal of Political Economy, 45, pp.133-148.

Santander, 2018 Bahrain: Foreign Investment [Online] Available at: https://en.portal.santandertrade.com/establish-overseas/bahrain/investing (Accessed On: 4th Feb 2018)

Santander, 2018 Jordan: Foreign Investment [ Online] Available at:

https://en.portal.santandertrade.com/establish-overseas/iordan/investing (Accessed On: 4th Feb 2018)

Santander, 2018 Kuwait: Foreign Investment [ Online] Available at:

https://en.portal.santandertrade.com/establish-overseas/kuwait/investing (Accessed On: 4th Feb 2018)

Santander, 2018 Oman: Foreign Investment [ Online] Available at:

https://en.portal.santandertrade.com/establish-overseas/oman/investing-3\#haut (Accessed On: 4th Feb 2018) 
Santander, 2018 Qatar: Foreign Investment [ Online] Available at:

https://en.portal.santandertrade.com/establish-overseas/qatar/investing-3 (Accessed On: 4th Feb 2018)

Santander. 2018 Saudi Arabia: Foreign Investment [Online] Available at:

https://en.portal.santandertrade.com/establish-overseas/saudi-arabia/foreign-investment (Accessed On: 4th Feb 2018)

Shahbaz, M., Nasreen, S., Abbas, F. and Anis, O., 2015. Does foreign direct investment impede environmental quality in high-, middle-, and low-income countries?. Energy Economics, 51, pp.275-287.

Shen, Z. and Puig, F., 2018. Spatial dependence of the FDI entry mode decision: Empirical evidence from emerging market enterprises. Management International Review, pp.1-23.

Solomon, E.M., 2017. Foreign direct investment, host country factors and economic growth. Ensayos Revista de Economía (Ensayos Journal of Economics), 30(1).

Ulrichsen, K.C., 2009. Internal and external security in the Arab Gulf states. Middle East Policy, 16(2), p.39.

YourMiddleEast, 2015. Foreign Investment in Arab states drops 8\% last year. [Online] Available at:

http://www.yourmiddleeast.com/business/foreign-investment-in-arab-states-drops-8-last-year_33841

[Accessed on: 30th January' 2018]

Zhang, K.H., 2001. Does foreign direct investment promote economic growth? Evidence from East Asia and Latin America. Contemporary economic policy, 19(2), pp.175-185.

\section{APPENDIX}

\section{Appendix A: Arab Countries}

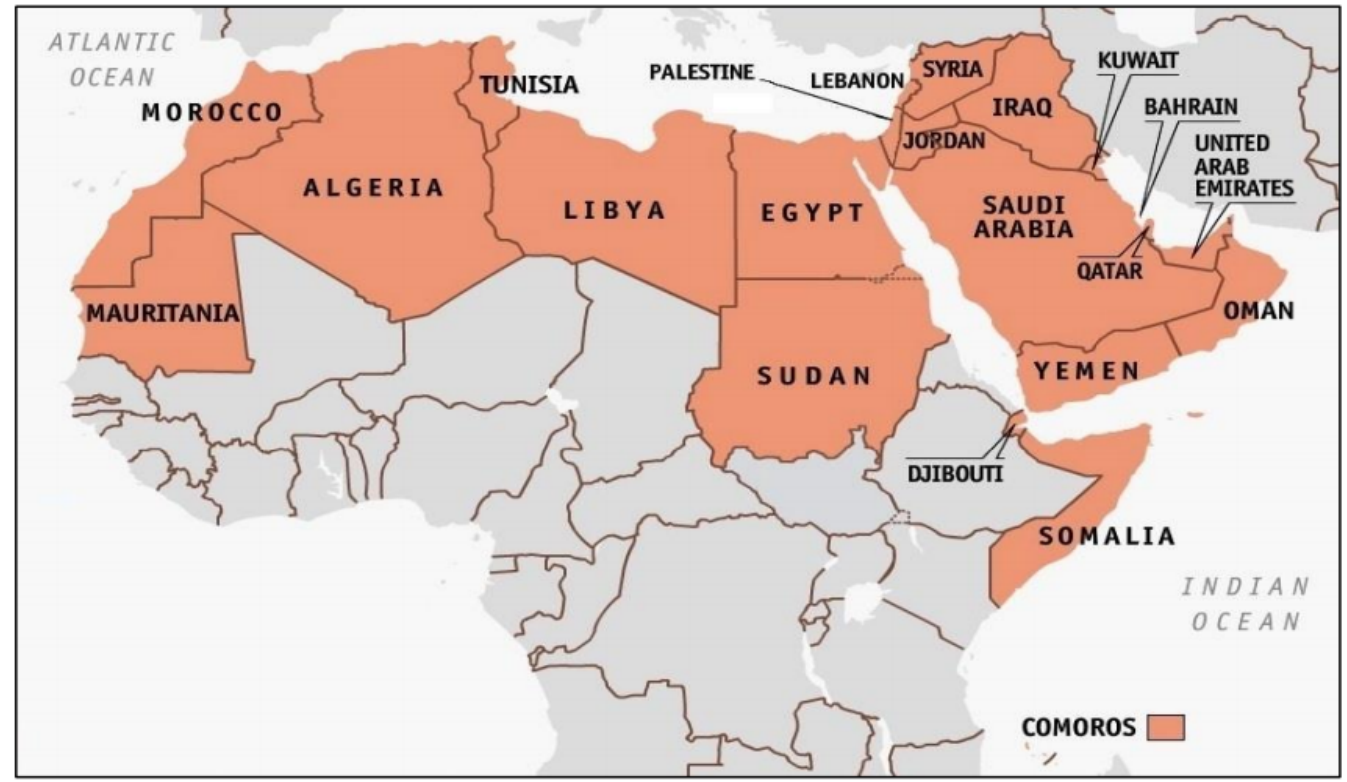

